\title{
Pengembangan Bahan Ajar Mata Kuliah Fisika Modern menggunakan Model ADDIE
}

\author{
Nengah Nitriani, Sahrul Saehana, dan Darsikin \\ nengah.nitriani@gmail.com \\ Program Studi Pendidikan Fisika FKIP Universitas Tadulako \\ Jl. Soekarno Hatta Km. 9 Kampus Bumi Tadulako Tondo Palu - Sulawesi Tengah
}

\begin{abstract}
Abstrak - Telah dilakukan penelitian pengembangan untuk menghasilkan bahan ajar mata kuliah fisika modern menggunakan model ADDIE. Pengembangan bahan ajar tersebut diharapkan dapat membantu mahasiswa dalam belajar mandiri dan memahami konsep fisika modern. Penelitian ini merupakan penelitian pengembangan yang mengacu pada model ADDIE yang meliputi 5 tahap, yaitu Analisis, Perancangan, Pengembangan, Implementasi, Evaluasi. Subjek penelitian ini adalah mahasiswa semester $V$ (lima) Program Studi Pendidikan Fisika Universitas Tadulako yang berjumlah 20 orang. Untuk mengetahui tingkat kelayakan bahan ajar tersebut maka dilakukan uji kelayakan terhadap produk. Uji kelayakan yang dilakukan terhadap produk terbagi menjadi tiga, uji kelayakan materi, uji kelayakan media, dan uji respon mahasiswa. Berdasarkan hasil uji coba dan analisis angket menunjukan bahwa rata-rata skor penilaian ahli materi sebesar 3,46 dikategorikan "Sangat Baik", rata-rata skor ahli media sebesar 3,46 dikategorikan "Sangat Baik", dan hasil analisis penilaian respon mahasiswa memberikan persentase respon tinggi (75,63\%). Hasil penelitian menunjukkan bahwa bahan ajar yang dikembangkan dapat dijadikan sebagai salah satu sarana dalam proses pembelajaran mahasiswa.
\end{abstract}

Kata Kunci: Bahan Ajar, Model ADDIE, Fisika Modern

\section{PENDAHULUAN}

Fisika merupakan cabang ilmu pengetahuan yang mempelajari tentang materi dan segala aktifitas fisik dari materi tersebut. Menurut Kamus Besar Bahasa Indonesia, fisika adalah ilmu alam, ilmu tentang zat dan energi, seperti panas, cahaya, dan bunyi; ilmu yang membahas materi, energi, dan interaksinya. Menurut Tipler (1998) fisika adalah ilmu pengetahuan yang paling fundamental karena merupakan dasar dari semua bidang sains yang lain.[1]. Salah satu bagian ilmu fisika adalah fisika modern, yang mempelajari perilaku materi dan energi pada skala atomik dan partikel-partikel subatomik atau gelombang. Pada prinsipnya sama seperti dalam fisika klasik, namun materi yang dibahas dalam fisika modern adalah skala atomik atau subatomik dan partikel bergerak dalam kecepatan tinggi. Untuk partikel yang bergerak dengan kecepatan mendekati atau sama dengan kecepatan cahaya, perilakunya dibahas secara terpisah dalam teori relativitas khusus. (Kusminarto: 1992).[2].

Pada Program Studi Pendidikan Fisika salah satu mata kuliah penting yang mengalami beberapa permasalahan adalah mata kuliah Fisika Modern. Mata kuliah ini membahas konsep-konsep yang dikembangkan di awal abad 20. Dimana perumusan-perumusan dalam fisika klasik tidak lagi mampu menjelaskan fenomena-fenomena yang terjadi pada materi dengan skala atomik/subatomik atau partikel yang bergerak dengan kecepatan mendekati kecepatan cahaya (relativitas) yang tidak dapat diamati langsung oleh panca indera.

Berdasarkan hasil evaluasi terhadap mahasiswa Program studi Pendidikan Fisika tahun akademik 2014/2015 dan 2015/2016 menunjukkan bahwa rata-rata hasil belajar mata kuliah fisika modern masih rendah seperti pada Tabel 1 dan 2.

TABEL 1 PERSENTASE NILAI FISIKA MODERN TAHUN AKADEMIK $2014 / 2015$

\begin{tabular}{ccc}
\hline Nilai & Jumlah Mahasiswa & Persentase \\
\hline A & 13 orang & $11,93 \%$ \\
B & 49 orang & $44,96 \%$ \\
C & 30 orang & $27,52 \%$ \\
D & 14 orang & $12,84 \%$ \\
E & - & - \\
\hline Tunda $(\mathrm{T})$ & 109 orang & $2,75 \%$ \\
\hline Total & & $100 \%$ \\
\hline
\end{tabular}

TABEL 2 PERSENTASE NILAI FISIKA MODERN TAHUN AKADEMIK

\begin{tabular}{ccc}
\multicolumn{2}{c}{$2015 / 2016$} & \\
\hline \multirow{2}{*}{ Nilai } & Jumlah Mahasiswa & Persentase \\
\hline A & 21 orang & $16,15 \%$ \\
B & 54 orang & $41,54 \%$ \\
C & 44 orang & $33,85 \%$ \\
D & 8 orang & $6,15 \%$ \\
E & - & - \\
\hline Tunda $(\mathrm{T})$ & 3 orang & $2,31 \%$ \\
\hline Total & 130 orang & $100 \%$ \\
\hline
\end{tabular}

Berdasarkan Tabel 1 dari 109 mahasiswa terdapat $17(15,59 \%)$ mahasiswa yang tidak lulus serta $30(27,52 \%)$ mahasiswa yang memiliki nilai dalam kategori cukup (C) dan pada Tabel 2 dari 130 mahasiswa terdapat 11 
$(8,46 \%)$ mahasiswa yang tidak lulus serta 44 $(33,85 \%)$ mahasiswa yang memiliki nilai dalam kategori cukup (C). Hal ini menunjukkan bahwa Pengajaran mata kuliah Fisika Modern belum optimal.

Hasil wawancara dengan beberapa mahasiswa yang telah mengambil mata kuliah Fisika Modern menunjukkan bahwa mereka masih mengalami kesulitan dalam memahami konsep dan formulasi. Salah satu sebabnya adalah sulitnya memahami sumber ajar (buku referensi wajib) yang berdampak pada mahasiswa tidak memiliki kemampuan awal sehingga proses pembelajaran berpusat pada dosen yang menyebabkan mahasiswa menjadi dominan mendengarkan dan mencatat yang sekaligus menjadi salah satu faktor pembelajaran yang tidak aktif melibatkan mahasiswa. Oleh sebab itu, perlu dicarikan alternatif solusi untuk memecahkan masalah sumber ajar yang dapat memudahkan mahasiswa dalam memahami konsep.

Bahan ajar merupakan alternatif solusi menyelesaikan masalah tersebut. Bahan ajar adalah seperangkat bahan yang memuat materi atau isi pembelajaran yang "didesain" untuk mencapai tujuan pembelajaran (Sungkono, dkk, 2003),[3]. Bahan ajar juga merupakan komponen yang memiliki peran penting dalam proses pembelajaran. Ketersediaan bahan ajar dapat membantu mahasiswa dalam memperoleh informasi tentang materi pembelajaran. Beberapa asumsi tentang arti penting kedudukan bahan ajar yaitu: (1) membantu belajar secara perorangan; (2) memberikan keleluasaan penyiapan pembelajaran jangka pendek dan jangka panjang; (3) rancangan bahan ajar yang sistematis memberikan pengaruh yang besar bagi perkembangan sumber daya manusia secara perorangan; (4) memudahkan pengelolaan proses belajar mengajar secara sistematis; dan (5) memudahkan dalam belajar. [4].

Pengembangan bahan ajar dalam penelitian menggunakan model ADDIE. Benny, (2009) [5] menyatakan bahwa ADDIE merupakan salah satu model pengembangan yang rinci, sistematis, dan sederhana dengan lima langkah pengembangan yaitu Analysis Design, Development, Implementation, dan Evaluation, yang diarahkan pada peningkatan pemahaman konsep tentang Fisika Modern. Tujuan dari dikembangkannya bahan ajar ini adalah agar dapat menyusun bahan ajar yang baik, sehingga dapat digunakan sebagai sumber belajar yang memfasilitasi belajar fisika modern mahasiswa di perkuliahan secara mandiri.
Isi dan konsep bahan ajar yang disusun diharapkan mampu membantu mahasiswa untuk memahami materi fisika modern secara mendalam, membantu mahasiswa memberi makna materi yang dipelajari dalam kehidupan sehari-hari mahasiswa, serta dapat membantu mahasiswa dalam belajar mandiri dan memahami konsep Fisika Modern.

\section{METODE PENELITIAN}

Penelitian ini termasuk jenis penelitian dan pengembangan atau dikenal Research and Developement (R\&D) yaitu model penelitian yang digunakan untuk menghasilkan produk tertentu, dan menguji keefektifan produk tersebut. (Sugiyono, 2010).[6]. Penelitian yang dilakukan merupakan pengembangan bahan ajar mata kuliah fisika modern menggunakan model ADDIE. Model ADDIE terdiri dari lima tahapan yaitu analisis (analyse), perencanaan (design), pengembangan (development), pelaksanaan (implementation) dan evaluasi (evaluation).

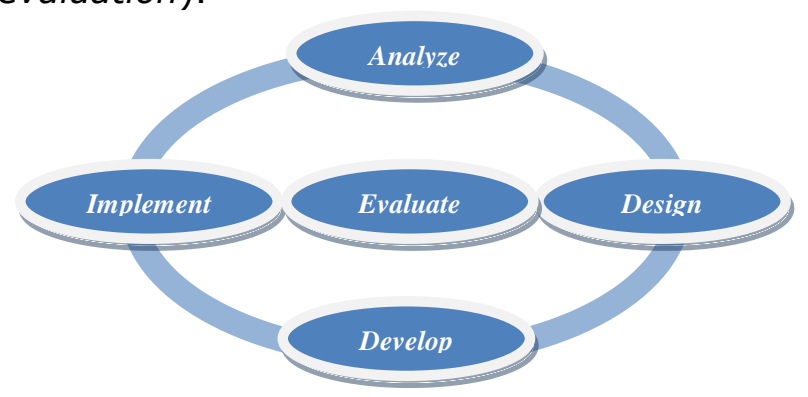

Gbr. 1. Model ADDIE

Penelitian pengembangan bahan ajar ini menggunakan model $A D D I E$, diadaptasi dari langkah-langkah model penelitian pengembangan oleh Sugiyono (2010), langkahlangkah penelitian secara umum dapat dilihat pada Gambar 2.

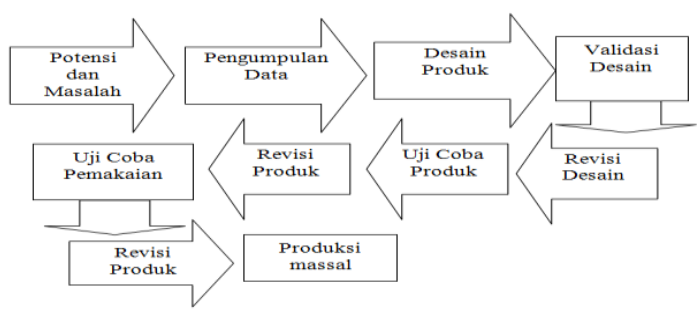

Gbr. 2. Langkah-langkah Metode Research and Development

Langkah-langkah dalam penelitian ini penelitian hanya sampai pada tahap revisi produk. Dari gambar 1 maka langkah-langkah yang dilaksanakan meliputi:

1. Potensi dan masalah

Penelitian dapat diangkat dari adanya potensi atau masalah. Potensi adalah segala sesuatu yang apabila didayagunakan 
akan memiliki nilai tambah (Sugiyono, 2010). Sedangkan masalah adalah penyimpangan antara kenyataan dan harapan.

2. Pengumpulan data

Setelah potensi masalah disajikan secara faktual, selanjutnya akan dilakukan pengumpulan bahan-bahan yang diperlukan untuk membuat bahan ajar. Bahan-bahan yang dibutuhkan seperti gambar-gambar sebagai pelengkap dan lain sebagainya.

3. Desain produk

Setelah dikumpulkan berbagai macam data yang dibutuhkan, maka selanjutnya proses pembuatan desain. Proses ini adalah proses dimana gambaran awal dari bahan ajar yang akan kita buat. Pada penelitian ini akan dibuat demo produk yang akan dikembangkan.

4. Validasi desain

Validasi ini berguna untuk mengetahui apakah produk yang dibuat layak diujikan atau tidak. Validasi dilakukan melalui diskusi dengan ahli. Ahli disini adalah ahli media dan ahli materi yang berkompeten di bidangnya.

5. Revisi desain

Setelah melewati proses validasi, maka diketahui kelemahan-kelemahan demo produk yang dibuat. Kelemahan tersebut kemudian dikurangi dengan memperbaiki bagian-bagian yang dirasa masih kurang.

6. Uji coba produk

Langkah selanjutnya adalah dengan menguji coba produk, Uji coba dilakukan oleh mahasiswa semester V (lima) Program Studi Pendidikan Fisika Universitas Tadulako.

7. Revisi produk

Langkah revisi merupakan langkah terakhir dari penelitian ini, dan setelah revisi maka produk sudah bisa digunakan. Selanjutnya penulisan laporan penelitian.

Penelitian ini dilaksanakan di Program Studi Pendidikan Fisika Fakultas Keguruan dan IImu Pendidikan Universitas Tadulako. Waktu pelaksanaan penelitian pengembangan ini dilakukan mulai bulan September 2016 s.d. Januari 2017. Subjek penelitian ini adalah seluruh mahasiswa semester $\mathrm{V}$ Program Studi Pendidikan Fisika. Penelitian ini adalah penelitian dan pengembangan dengan $u j i$ terbatas, maka hanya 20 mahasiswa yang diambil sebagai subjek penelitian untuk menilai kelayakan bahan ajar.

Instrumen yang digunakan dalam penelitian ini adalah dengan teknik angket (Quesioner) bertujuan untuk mengukur kelayakan isi/materi dan media dalam pembelajaran. Angket diberikan kepada ahli materi, ahli media, dan mahasiswa sesuai kebutuhan dan tujuannya. Jenis data terdiri dari data kuantitatif dan kualitatif. Data kuantitatif berupa skor penilaian seluruh bagian dan isi bahan ajar berdasar hasil angket uji validitas dengan skala likert berupa angka 1, 2, 3 dan 4. Data kualitatif merupakan evaluasi dari validator (tanggapan, masukan, saran dan kritik) yang tercantum dalam angket maupun diskusi langsung yang digunakan sebagai pertimbangan dalam melakukan revisi terhadap bahan ajar.

Teknik analisis yang digunakan untuk menganalisis data hasil validasi adalah perhitungan nilai rata-rata. Penentuan teknik analisis nilai rata-rata ini berdasarkan pendapat dari Arikunto (2006),[7] yang menyatakan bahwa untuk mengetahui peringkat nilai akhir pada setiap butir angket penelitian, jumlah nilai yang diperoleh dibagi dengan banyaknya responden yang menjawab angket penilaian tersebut. Rumus untuk menghitung nilai ratarata adalah sebagai berikut.

$$
\bar{X}=\frac{\sum x}{n}
$$

Keterangan:

$\overline{\boldsymbol{X}} \quad$ : nilai rata-rata dalam tiap butir pernyataan

$\sum x \quad$ : jumlah nilai dari seluruh penilaian dalam

tiap butir pernyataan

$n \quad$ : jumlah butir pernyataan

Mengubah skor rata-rata yang diperoleh ke dalam bentuk kualitatif berdasarkan Tabel 3 (Widoyoko, 2012).[8]

\begin{tabular}{cc} 
TABEL 3 & KRITERIA NILAI PRODUK \\
\hline Skor Rata-Rata & Kriteria \\
\hline $3,25<\bar{X} \leqslant 4,00$ & Sangat baik (SB) \\
$2,50<\bar{X} \leqslant 3,25$ & Baik (B) \\
$1,75<\bar{X} \leqslant 2,50$ & Kurang (K) \\
$1,00 \leqslant \bar{X} \leqslant 1,75$ & Sangat Kurang (SK) \\
\hline
\end{tabular}

Analisis data respon mahasiswa serupa dengan analisis kualitas penilaian produk. Ratarata skor dari angket respon selanjutnya diubah ke dalam bentuk kualitatif berdasarkan Tabel 4 .

TABEL 4 KRITERIA KATEGORI RESPON MAHASISWA

\begin{tabular}{cc}
\hline Skor Rata-Rata & Kriteria \\
\hline $3,25<\bar{X} \leqslant 4,00$ & Sangat Setuju (SS) \\
$2,50<\bar{X} \leqslant 3,25$ & Setuju (S) \\
$1,75<\bar{X} \leqslant 2,50$ & Tidak Setuju (TS) \\
$1,00 \leqslant \bar{X} \leqslant 1,75$ & Sangat Tidak Setuju (STS) \\
\hline
\end{tabular}

Skor penilaian atau tingkat kelayakan baik setiap aspek maupun keseluruhan terhadap bahan ajar menggunakan Tabel 4, sebagai 
acuan penilaian data yang dihasilkan dari validitas ahli materi, ahli media, serta ujicoba pada mahasiswa agar mempermudah dalam pemberian suatu kriteria nilai bahwa bahan ajar mata kuliah fisika modern menggunakan model ADDIE yang dikembangkan sudah layak atau belum untuk digunakan.

\section{HASIL DAN PEMBAHASAN}

A. Hasil Penelitian

1. Validasi Ahli Materi

Ahli materi adalah validator yang dipilih untuk menilai kelayakan isi, kelayakan penyajian, dan kontekstual pada bahan ajar yang dikembangkan. Pada tahap uji kelayakan materi dilakukan oleh seorang dosen Pendidikan Fisika. Dari hasil validasi materi didapatkan hasil penilaian seperti pada Tabel 5 s.d. 7.

TABEL 5 HASIL VALIDASI ASPEK KELAYAKAN ISI BAHAN AJAR

\begin{tabular}{clcc}
\hline No & \multicolumn{1}{c}{ Indikator } & $\begin{array}{c}\text { Skor } \\
\text { Indikator }\end{array}$ & Klasifikasi \\
\hline 1 & $\begin{array}{l}\text { Kesesuaian materi } \\
\text { dengan SK dan KD }\end{array}$ & 3,66 & $\begin{array}{c}\text { Sangat } \\
\text { Baik }\end{array}$ \\
2 & $\begin{array}{l}\text { Keakuratan materi } \\
\text { Kemutakhiran }\end{array}$ & 3,42 & $\begin{array}{c}\text { Sangat } \\
\text { Baik }\end{array}$ \\
3 & $\begin{array}{l}\text { materi } \\
\text { Mendorong } \\
\text { keingintahuan }\end{array}$ & 3,00 & Baik \\
& Rata-rata & 3,00 & $\begin{array}{c}\text { Sangat } \\
\text { Baik }\end{array}$ \\
\hline
\end{tabular}

TABEL 6 HASIL VALIDASI ASPEK KELAYAKAN PENYAJIAN

\begin{tabular}{|c|c|c|c|}
\hline No & Indikator & $\begin{array}{c}\text { Skor } \\
\text { Indikator }\end{array}$ & Klasifikasi \\
\hline 1 & Teknik Penyajian & 3,50 & $\begin{array}{l}\text { Sangat } \\
\text { Baik }\end{array}$ \\
\hline 2 & $\begin{array}{l}\text { Pendukung } \\
\text { Penyajian }\end{array}$ & 3,57 & $\begin{array}{c}\text { Sangat } \\
\text { Baik }\end{array}$ \\
\hline 3 & $\begin{array}{l}\text { Penyajian } \\
\text { Pembelajaran }\end{array}$ & 3,00 & Baik \\
\hline 4 & $\begin{array}{l}\text { Koherensi dan } \\
\text { Keruntutan Alur Pikir }\end{array}$ & 4,00 & $\begin{array}{l}\text { Sangat } \\
\text { Baik }\end{array}$ \\
\hline & Rata-rata & 3,52 & $\begin{array}{c}\text { Sangat } \\
\text { Baik }\end{array}$ \\
\hline
\end{tabular}

TABEL 7 HASIL VALIDASI KESESUAIAN DENGAN PENDEKATAN

\begin{tabular}{cccc}
\multicolumn{3}{c}{ KONTEKSTUAL } & \\
\hline No & \multicolumn{1}{c}{ Indikator } & $\begin{array}{c}\text { Skor } \\
\text { Indikator }\end{array}$ & Klasifikasi \\
\hline 1 & $\begin{array}{l}\text { Hakekat } \\
\text { Kontekstual }\end{array}$ & 3,00 & Baik \\
2 & $\begin{array}{l}\text { Komponen } \\
\text { Kontekstual }\end{array}$ & 3,67 & $\begin{array}{c}\text { Sangat } \\
\text { Baik }\end{array}$ \\
\hline & Rata-rata & 3,34 & $\begin{array}{c}\text { Sangat } \\
\text { Baik }\end{array}$ \\
\hline
\end{tabular}

Secara umum, hasil yang diperoleh dari penilaian ahli materi dapat dilihat pada Tabel 8 .
TABEL 8 HASIL VALIDASI KELAYAKAN OLEH AHLI MATERI

\begin{tabular}{|c|c|c|c|}
\hline No & Aspek Penilaian & $\begin{array}{l}\text { Rata-rata } \\
\text { jumlah nilai }\end{array}$ & Kategori \\
\hline 1 & Kelayakan Isi & 3,52 & $\begin{array}{l}\text { Sangat } \\
\text { Baik }\end{array}$ \\
\hline 2 & $\begin{array}{l}\text { Kelayakan } \\
\text { Penyajian }\end{array}$ & 3,52 & $\begin{array}{l}\text { Sangat } \\
\text { Baik }\end{array}$ \\
\hline 3 & $\begin{array}{l}\text { Kesesuaian dengan } \\
\text { pendekatan } \\
\text { kontekstual }\end{array}$ & 3,34 & $\begin{array}{c}\text { Sangat } \\
\text { Baik }\end{array}$ \\
\hline & Total & 3,46 & $\begin{array}{c}\text { Sangat } \\
\text { Baik }\end{array}$ \\
\hline
\end{tabular}

Adapun tingkat pencapaian yang diperoleh dari hasil penilaian angket uji coba ahli materi yang dihitung dengan menggunakan Persamaan 1 , diperoleh jumlah nilai total sebesar 3,46 nilai tersebut menunjukkan bahwa materi termasuk dalam kategori sangat baik.

Adapun saran dan kritik oleh ahli adalah:

1) Pada Bab II ketidakjelasan kalimat Kegagalan Transformasi Galilei

2) Pada Dinamika Relativistik, sebaiknya direpresentasikan secara matematik bukti keberadaan partikel tak bermassa

3) Pada Bab III Sifat Partikel dari Gelombang yaitu Radiasi Benda Hitam sebaiknya dipaparkan teori klasik radiasi benda hitam.

4) Pada Bab III, teori Efek Fotolistrik dari Einstein sebaiknya sebelum eksperimen yang membuktikan teori tersebut.

\section{Validasi Ahli Media}

Ahli media adalah validator yang dipilih untuk menilai kelayakan kegrafikan dan aspek kelayakan bahasa. Pada tahap uji kelayakan media dilakukan oleh seorang dosen Pendidikan Fisika. Hasil penilaian oleh ahli media dapat dilihat pada Tabel 9 dan 10.

TABEL 9 HASIL UJI KELAYAKAN KEGRAFIKAN

\begin{tabular}{cccc}
\hline No & \multicolumn{1}{c}{ Indikator } & $\begin{array}{c}\text { Skor } \\
\text { Indikator }\end{array}$ & Klasifikasi \\
\hline 1 & Ukuran Bahan Ajar & 4,00 & Sangat baik \\
2 & $\begin{array}{l}\text { Desain Sampul } \\
\text { Bahan Ajar (Cover) }\end{array}$ & 3,33 & Sangat Baik \\
3 & $\begin{array}{l}\text { Desain Isi Bahan } \\
\text { Ajar }\end{array}$ & 3,00 & baik \\
\hline & Rata-rata & 3,44 & Sangat Baik \\
\hline
\end{tabular}

TABEL 10 HASIL KELAYAKAN UJI BAHASA

\begin{tabular}{|c|c|c|c|}
\hline No & Indikator & $\begin{array}{c}\text { Skor } \\
\text { Indikator }\end{array}$ & Klasifikasi \\
\hline 1 & Lugas & 3,33 & Sangat baik \\
\hline 2 & Komunikatif & 3,00 & Baik \\
\hline 3 & $\begin{array}{l}\text { Dialogis dan interaktif } \\
\text { Kesesuaian dengan }\end{array}$ & 3,50 & Sangat baik \\
\hline 4 & $\begin{array}{l}\text { perkembangan peserta } \\
\text { didik }\end{array}$ & 3,50 & Sangat baik \\
\hline 5 & $\begin{array}{l}\text { Kesesuaian dengan } \\
\text { kaidah bahasa }\end{array}$ & 4,00 & Sangat baik \\
\hline 6 & $\begin{array}{l}\text { Penggunaan istilah, } \\
\text { simbol, atau ikon }\end{array}$ & 3,50 & Sangat baik \\
\hline & Rata-rata & 3,47 & Sangat Baik \\
\hline
\end{tabular}


Secara umum, hasil yang diperoleh dari penilaian ahli media seperti pada Tabel 11 .

\begin{tabular}{|c|c|c|c|}
\hline No & Indikator & $\begin{array}{c}\text { Skor } \\
\text { Indikator }\end{array}$ & Klasifikasi \\
\hline 1 & $\begin{array}{l}\text { Kelayakan } \\
\text { kegrafikan }\end{array}$ & 3,44 & Sangat baik \\
\hline 2 & Kelayakan bahasa & 3,47 & $\begin{array}{c}\text { Sangat } \\
\text { Baik }\end{array}$ \\
\hline & Rata-rata & 3,46 & $\begin{array}{c}\text { Sangat } \\
\text { Baik }\end{array}$ \\
\hline
\end{tabular}

Adapun tingkat pencapaian yang diperoleh dari hasil penilaian angket uji coba ahli media yang dihitung dengan menggunakan Persamaan 1 , diperoleh jumlah nilai rata-rata sebesar 3,46 nilai tersebut menunjukkan bahwa bahan ajar mata kuliah Fisika Modern termasuk dalam kriteria sangat baik.

\section{Hasil Angket Respon Mahasiswa}

Pada tahap ini dilakukan uji coba terbatas di Program Studi Pendidikan Fisika Universitas Tadulako. Hasil uji coba yang dilakukan terhadap 20 mahasiswa semester $\mathrm{V}$ menunjukkan bahwa bahan ajar menggunakan model ADDIE layak untuk digunakan dalam proses pembelajaran fisika modern. Hal tersebut dapat dilihat pada Tabel 12.

TABEL 12 HASIL ANALISIS RATA-RAZTA PENILAIAN BERDASARKAN RESPON MAHASISWA

\begin{tabular}{clc}
\multicolumn{4}{c}{ RESPON MAHASISWA } & \multicolumn{1}{c}{\begin{tabular}{c}
\multicolumn{1}{c}{ Persentase } \\
$(\%)$
\end{tabular}} \\
\hline No. & \multicolumn{1}{c}{$\begin{array}{l}\text { Bahan ajar ini menjelaskan suatu } \\
\text { konsep menggunakan ilustrasi } \\
\text { masalah yang berkaitan dengan } \\
\text { kehidupan sehari-hari. }\end{array}$} & 76,25 \\
Bahan ajar ini menggunakan \\
contoh-contoh soal yang berkaitan \\
dengan masalah kehidupan sehari- \\
hari.
\end{tabular}

12 Tampilan bahan ajar ini menarik. 75

13 Bahan ajar ini membuat saya 75 senang mempelajari Fisika Modern. Dengan menggunakan bahan ajar

14 ini dapat menambah keinginan untuk belajar.

Dengan menggunakan bahan ajar

15 ini membuat belajar saya lebih terarah dan runtut.

Dengan adanya ilustrasi di setiap

16 awal materi dapat memberikan motivasi untuk mempelajari materi. Dengan menggunakan bahan ajar

17 ini dapat membuat belajar fisika modern tidak membosankan.

18 Bahan ajar ini dapat saya gunakan untuk belajar mandiri.

Dari Tabel 12 dapat diketahui bahwa respon mahasiswa memberikan persentase respon tinggi $(75,63 \%)$. Pada angket respon juga menyertakan kemandirian belajar (poin 18). Rata-rata skor pada poin 18 adalah $86,25 \%$. Dapat diartikan bahwa mahasiswa setuju bahwa bahan ajar dapat membantu mereka dalam belajar mandiri di rumah.

Pada kolom alasan respon mahasiswa terdapat beberapa alasan yang dapat dijadikan saran dari para mahasiswa, antara ain: (1) cover agar didesain lebih menarik, baik dari segi warna dan gambar, (2) pengembangan isi setiap bab lebih diperjelas dan disesuaikan dengan perkembangan terkini, (3) revisi terhadap spasi yang digunakan, sehingga pengetikan beraturan, (4) revisi terhadap beberapa redaksi atau kata yang salah ketik, dan (5) mengecek rangkuman agar dapat merangkum semua isi materi tiap-tiap subbab.

\section{B. Pembahasan}

Penelitian pengembangan ini bertujuan untuk menghasilkan bahan ajar mata kuliah fisika modern menggunakan model ADDIE. Dalam pengembangan bahan ajar fisika modern ini diharapkan bermanfaat bagi mahasiswa dalam memudahkan memahami konsep-konsep fisika modern dan diharapkan dapat dijadikan tambahan referensi untuk penelitian selanjutnya tentang pengembangan bahan ajar fisika modern menggunakan model ADDIE. Fungsi dari penyusunan bahan ajar ini adalah sebagai pedoman bagi mahasiswa yang mengarahkan semua aktivitasnya dalam proses pembelajaran, sekaligus merupakan subtansi kopetensi yang seharusnya dipelajari, dan sebagai alat evaluasi pencapaian pengetahuan mahasiswa setelah mengikuti pembelajaran.

Analisis data hasil pengembangan bahan ajar ini didasarkan pada hasil validasi dan uji coba terbatas. Desain uji coba yang digunakan dalam penelitian ini adalah uji kelayakan terhadap 
produk. Uji coba dilakukan oleh satu dosen fisika sebagai ahli materi, satu dosen fisika sebagai ahli media, serta dua puluh mahasiswa semester V Program Studi Pendidikan Fisika Universitas Tadulako.

Berdasarkan penilaian ahli materi yang dilakukan oleh dosen fisika Universitas Tadulako yaitu bapak Drs. H. Kamaluddin, M.Si, aspek yang dinilai dari bahan ajar ini meliputi kelayakan isi, kelayakan penyajian, dan kesesuaian dengan pendekatan kontekstual. Rata-rata hasil penilaian dari uji kelayakan isi adalah 3,52, rata-rata dari uji kelayakan penyajian adalah 3,52 , dan rata-rata penilaian dari uji kesesuaian dengan pendekatan kontekstual adalah 3,34. Hasil rata-rata penilaian uji kelayakan isi, uji kelayakan penyajian dan uji kesesuaian dengan pendekatan kontekstual didapatkan jumlah rata-rata keseluruhan dari ahli materi yaitu 3,46 dan dikategorikan "Sangat Baik". Dari hasil tersebut ahli materi menyatakan bahwa bahan ajar ini layak diuji cobakan di lapangan dengan revisi.

Hasil penilaian ahli media yang dilakukan oleh dosen fisika Universitas Tadulako yaitu bapak Drs. Yusuf Kendek Paluin, M.Pd, aspek yang dinilai dari bahan ajar ini meliputi kelayakan kegrafikan dan kelayakan bahasa. Rata-rata hasil penilaian dari uji kelayakan kegrafikan 3,44 dan rata-rata dari uji kelayakan bahasa adalah 3,47 . Hasil rata-rata penilaian uji kelayakan kegrafikan dan uji kelayakan bahasa didapatkan jumlah rata-rata keseluruhan dari ahli media yaitu 3,46 dan dikategorikan "Sangat Baik". Dari hasil tersebut ahli media menyatakan bahwa bahan ajar ini layak diuji cobakan di lapangan tanpa ada revisi.

Hasil di atas menunjukkan bahwa bahan ajar ini memungkinkan mahasiswa untuk belajar secara mandiri karena di dalam bahan ajar ini telah dilengkapi dengan materi yang sesuai dengan tema maupun Standar Kompetensi dan Komptensi Dasar, terdapat contoh dan ilustrasi yang disajikan secara kontekstual artinya materi yang disajikan sesuai dengan lingkungan mahasiswa, terdapat soal-soal latihan, rangkuman materi yang membuat mahasiswa dapat mengetahui tingkat penguasaan materi serta umpan balik yang memungkinkan mahasiswa untuk mengukur kemampuannya sendiri. Hasil ini menunjukkan bahwa bahan ajar ini dapat digunakan oleh mahasiswa dalam proses pembelajaran karena menyajikan permasalahan yang kontekstual dengan lingkungan sehingga mahasiswa mudah memahami materi.

Setelah dilakukan validasi ahli media dan ahli materi langkah selanjutnya adalah uji skala kecil atau uji terbatas. Uji terbatas ini bertujuan untuk mengetahui respon mahasiswa terhadap penggunaan bahan ajar ini. Bahan ajar hasil pengembangan diujikan dalam uji coba lapangan skala kecil kepada 20 mahasiswa. Tujuan pelaksanaan uji coba lapangan skala kecil adalah untuk mendapatkan gambaran respon mahasiswa terhadap bahan ajar yang dikembangkan. Mahasiswa memberi tanggapan terhadap materi, bahasa, dan ketertarikan menggunakan bahan ajar tersebut. Hasil analisis respon mahasiswa terhadap bahan ajar fisika modern menggunakan model ADDIE yang dikembangkan karena tipe pernyataannya bersifat positif, maka nilai (score) untuk tiap pilihan jawabannya adalah sebagai berikut 4 (Sangat setuju), 3 (Setuju), 2 (Tidak setuju), dan 1 (Sangat tidak setuju).

Uji terbatas dilakukan terhadap 20 mahasiswa semester $\mathrm{V}$ Program Studi Pendidikan Fisika Universitas Tadulako, mahasiswa diberi angket yang mempunyai 18 item pernyataan dan ada 4 opsi pilihan. Hasil angket tertutup menunjukkan bahwa persentase pencapaian bahan ajar adalah $75,63 \%$. Hal ini berarti persentase bahan ajar berada pada kualifikasi baik yang hanya memerlukan sedikit revisi sehingga bahan ajar yang dibuat layak digunakan sebagai sarana belajar mahasiswa.

Bahan ajar yang telah dikembangkan memiliki beberapa keunggulan seperti: (1) Penyajian materi dalam bahan ajar dimulai dari yang mudah ke sukar dan dari yang konkret ke abstrak, (2) Bahasa yang digunakan sederhana dan mudah dimengerti, (3) Bahan ajar dapat membuat belajar mahasiswa lebih terarah dan runtut karena susunan materi yang terstruktur, (4) Bahan ajar dapat digunakan untuk belajar mandiri, (5) Terdapat ilustrasi gambar serta penjelasan yang membuat mahasiswa mudah mengerti konsep fisika modern, (6) Terdapat beberapa pembuktian persamaan fisika modern, (7) Terdapat contoh soal dan soal latihan tiap subbab sehingga mahasiswa bisa mengukur kopetensi yang dimilikinya, dan (8) Terdapat kunci jawaban untuk soal latihan.

Berdasarkan uraian di atas dapat disimpulkan bahwa bahan ajar fisika modern menggunakan model ADDIE dimaksudkan untuk membiasakan mahasiswa bahwa apa yang dipelajari di perkuliahan sangat banyak manfaatnya untuk kehidupan nyata, materi yang dipelajari di perkuliahan bukanlah materi abstrak yang tidak ada kaitannya dengan kehidupan sehari-hari. Hal ini sesuai dengan pendapat Wayan Sudarsana dalam komentarnya pada angket respon mahasiswa "Dalam bahan ajar ini menyajikan materi yang 
dijelaskan dengan fenomena kehidupan seharihari, sehingga mudah dipahami dan pada contoh soal bahan ajar ini menggunakan bagaimana fenomena kehidupan sehari-hari yang berhubungan dengan fisika modern ". Bahan ajar menggunakan model ADDIE ini membuat mahasiswa aktif untuk mengkonstruksi pengetahuan dan pemahaman mereka sendiri. Hasil penelitian ini didukung oleh pendapat Sarwanto (2012) bahwa penggunaan bahan ajar dalam pembelajaran fisika lebih efektif untuk meningkatkan motivasi belajar serta meningkatkan kemampuan kognitif mahasiswa.

Penelitian pengembangan bahan ajar fisika modern secara keseluruhan sangat layak digunakan sesuai dengan penilaian oleh ahli dan mahasiswa serta dapat memudakan mahasiswa dalam memahami materi fisika modern dengan mengaitkannya dalam kehidupan sehari-hari. Namun hal tersebut tidak lepas dari keterbatasan-keterbatasan peneliti selama melaksanakan penelitian ini, diantaranya peneliti masih terbatas pada satu Program Studi saja dan belum dilakukan uji coba di Program Studi yang berbeda misalnya Program Studi Fisika (Fisika Murni). Selain itu keterbatasan waktu peneliti sehingga uji coba tidak dilakukan secara tuntas dan penyebaran angket respon mahasiswa dilakukan di luar jam perkuliahan.

\section{KESIMPULAN DAN SARAN}

\section{A. Kesimpulan}

Berdasarkan hasil analisis dan pembahasan, maka penelitian ini dapat disimpulkan bahwa:

1) Telah dihasilkan bahan ajar fisika modern berdasarkan langkah-langkah pengembangan yaitu menganalisis adanya masalah, mengumpulkan data, mendesain produk, validasi produk, revisi produk, serta uji coba produk.

2) Pada hasil uji coba ahli materi didapatkan skor penilaian rata-rata sebesar 3,46 dan dikategorikan "Sangat Baik", analisis penilaian ahli media didapatkan skor ratarata sebesar 3,46 dan dikategorikan "Sangat Baik". Hasil analisis penilaian respon mahasiswa memberikan persentase respon tinggi (75,63\%). Hal ini menunjukkan bahwa bahan ajar yang dikembangkan ini dapat dijadikan sebagai salah satu sarana pembelajaran bagi mahasiswa.

B. Saran

Berdasarkan penelitian yang dilakukan, adapun saran peneliti dalam mengembangkan bahan ajar adalah:

1) Bahan ajar fisika modern menggunakan model ADDIE untuk mahasiswa semester $\mathrm{V}$ Program Studi Pendidikan Fisika ini perlu disempurnakan lagi. Dalam penelitian dan pengembangan lebih lanjut perlu memperhatikan langkah-langkah pengembangannya karena pada penelitian ini hanya sampai pada tahap keempat model ADDIE, sehingga perlu dilakukan tahap evaluasi untuk hasil penelitian yang lebih baik sehingga menghasilkan produk yang lebih berkualitas.

2) Perlu dikembangkan bahan ajar fisika modern dengan materi yang lebih disesuaikan dengan kebutuhan mahasiswa serta menyajikan kasus-kasus yang lebih kompleks namun bersifat kontekstual, sehingga dapat memperkaya sumber belajar mahasiswa dan dapat digunakan sebagai penunjang dalam penerapan kurikulum selanjutnya.

3) Ditinjau dari keterbatasan waktu peneliti dalam melaksanakan uji coba, maka peneliti menyarankan agar penelitian selanjutnya dapat dilaksanakan uji coba secara luas di Program Studi lain misalnya Program Studi Fisika (Fisika Murni).

\section{DAFTAR PUSTAKA}

[1] Tipler, P. A., (1998). Fisika untuk Sains dan Teknik Jilid I (Terjemahan), Jakarta: Penerbit Erlangga Jilid I.

[2] Kusminarto. (1992). Pokok-pokok Fisika Modern. Yogyakarta: FMIPA UGM

[3] Sungkono. (2003). Pengembangan Dan Pemanfaatan Bahan Ajar Modul dalam Proses Pembelajaran. Makalah Yogyakarta: FIP UNY

[4] Hernawan, A.H., Permasih dan Dewi, L. (2008). Pengembangan Bahan Ajar. Jakarta: UPI (KTI).

[5] Pribadi, B.A. (2009). Model Desain Sistem Pembelajaran. Jakarta: Dian Rakyat

[6] Sugiyono. (2010). Metode Penelitian Kuantitatif Kualitatif dan $R \& D$, Bandung: Alfabeta

[7] Arikunto, S. (2006). Prosedur Penelitian: Suatu Pendekatan Praktik. Jakarta: Rineka Cipta

[8] Widoyoko. (2012). Teknik Penyusunan Instrumen Penelitian. Yogyakarta: Pustaka Pelajar 